UDC 821.151

https://doi.org/10.31548/philolog2021.03.112

\title{
A PERSUASIVE FORCE OF PUNS IN BRITISH ADVERTISING
}

\author{
L. O. ShanAIEVA-TSYMBAL, PhD in Public Administration, Associate Professor, \\ National University of Life and Environmental Sciences of Ukraine \\ E-mail: almi2004@ukr.net \\ http://orcid.org/0000-0002-4571-3827
}

\begin{abstract}
In the article an important role of puns in British advertising has been widely studied. Also it is a subject of interest in modern culture, linguistics, communication, popular psychologyand marketing.Today an important role of our social life plays advertising. It has a great influence on our life and may affect on us in various spheres. Today's advertisements also inform and guide many of the important decisions we make,not just the cars we drive but whether we take entrepreneurial risks, choose to live a healthy lifestyle, plan ahead for retirement or donate to charity. Moreover, it representsspecific sidesof our society's valuation and frame. Advertising humor refers primarily to the ability of audiences to respond positively when one or others are portrayed in a playful manner. Attention is simply the degree to which consumers focus on stimuli within their sensory field. Humor is inherently attractive to most consumers because it is a major and pleasurable component of our cultural value system. A positive relationship between humor and attracting attention has been found across many different types of situations. It has been recommended for use in sales presentations, educational settings, training sessions, after-dinner speeches, and in the advertising of many different types of products. In the process of creating advertisements, language, option of demonstrationis of crucial significance.

English pun is a common language phenomenon. This effective rhetorical device is common in literary texts, cinema, and television comedy shows. Puns in advertising, as a technical way of communicating between advertisers and customers, play a great role in attracting people's attention. Punning is one of the most common forms of speech play which can enhance the appeal of a language and strengthen its informative effect.One of the most intriguing aspects of pun is the inter connection among culture and language, which can show the disambiguation of the appointed dual meanings closely stimulating or challenging, mostly if there viewer is not a natural speaker. On the other hand, it is not always easy for consumers to understand the wordplay, as well as jokes are based on homophones and homonyms.

Keywords: information, humor, advertising,persuasion, force, media, the Internet, press, puns, advertisers, customers, attention, values, marketing, culture, psychology, linguistics.
\end{abstract}

Introduction. We are existing in an age of information outbreak in which advertising appears to be anirreplaceablebuilding obstruction of the media.TV, Radio, the press, the Internet are financially induced to introduce ads.

What kinds of choices make an adgreatlyefficient issomething eminent to beobservedfrom alinguistic view. The aspectfor importantacademic study on pun in advertising was paved by many doctoral dissertations. The works dealt with humor, puns and persuasion.

Thus, the purpose of research is to provide an insight into the language of advertising, humor, pun or wordplay in particular.

Methods.In order to solve the different problems that the puns caused, OxfordEnglishDictionary was used, various thesauruses, encyclopedias and parallel texts have been consulted, as well as various parallel texts found on the Internet.

Analysis of the latest studies and publications. Works on puns in advertising were published by B. Sternthal and S. Craig (1973), P. J. Kelly and P. J. Solomon (1975), D. Ogilvy and L. Xiang (1982) [2, p.68]. Among a great number of questions aiming at solving the problem of humor in advertising, a special place is occupied by the question of the use of puns in print advertisements. It was studied by V. B. Sosnovskaya, Gulas C. S., A. Goddard, J. Wen, K. Tanaka, F. Abass, Y. Li, A. Mirabela, W. Nash, A. M. Zwicky, [1;3;4;5;6;7]. Nowadays, the study of pun in the language of advertising has extended tomakecertainty anddrawscientific attention.

According to Prof. I. R. Galperin, the pun is a stylistic device which is based on the interaction of two well-known meanings of a word or a phrase. There need not necessarily be a word in the sentence to which the pun-word refers, but like any other stylistic device, it must depend on a context. Oxford English Dictionary determinespun as the applyingof words in such aspect as tooffer two or moreassociations or different meanings, or the usage oftwo or more similarly words ornearly alike sound with another meanings, so as toemita funny effect [7]. From the precise definition,the construction of English puns originates from twoparts, one is from the sounding of the given words andthe second is from the content of the given words.

Results. Thereare several classifications of

(C) L. O. Shanaieva-Tsymbal

«International journal of philology» | «Міжнародний філологічний часопис» Vol. 12, № 3, 2021 
puns. The first is represented by A. M. Zwicky and E. D. Zwicky who suggest that there are two types of the pun: perfect and imperfect. The perfect pun includes similar spelling and the same pronunciation, e.g.: Pillsbury Flower Company: Everybody kneads it.

"Kneads" in the sentence meaning "to rub flour" is homonymous with the word "needs" meaning "to want", which makes this advertisement extremely impressing and persuasive.

Imperfect puns are based on the system of the half in verse, e.g.: A man wanted to buy his wife some anemones, her favorite flower. Unfortunately, all the florists had left and there were a few stems of the feathery ferns he used for decoration. The husband presented these rather shamefacedly to his wife. "Never mind, darling", she said, "with fronds like these, who needs anemones?" (target-friends, pun- frond's targetenemies; pun - anomones) [3,p.493].

In accordance with the J.Wen's book "English Writing and Rhetoric", there are 4 types of English puns:

- homophonic pun,

- paronomasia,

- antalaclasis, and

- sylleptic pun.

Homophone is each of two or more words having the same pronunciation but different meanings, origins, or spelling [7]. One exact example for the homophonic pun is: Telephone Advertisement: Make your every hello a real good-buy.

In the clausethe words "good-buy" have the same sounding, hence it arousesthe association of good-bye to the users.

Paranomasia is the usage of two wordswhich are analogical or have the samesounding but with another meaning. A typical example of paronomasia is: Shave Road Signs in Burma: Drunk drivers often put the quart before the hearse.

In this advertising "quart" has the same sound to cartand hearse sounds like "horse". Quart is a dimension for alcoholand hearse is aspecific vehicle, which carries dead bodies. The purpose of the use of use of pun in this case is tomake fun of the drunk drivers who aretaking the risk of their own livesdriving drunkandrecalls readers of thesignificance of driving safety.

Antalaclasiaappeals to a wordwhich can be used twice or more,but always with a different meaning. Sample:

Mild (cigarette): A mild way

Make it a Mild Smoke.

Smooth, rich, rewarding.

The company achieves its goalsof brand propaganda during the usage of this punby persuading the smokers to buy the cigarettes.Furthermore, puns do not just communicate one interpretation while activating another, but actually communicate both meanings. One word presents two or more images. Here "mild" has dyad meanings. The first meaning is "soft, gentle" and the secondis the mark of a cigarette.

A sylleptic pun is the term used as a pun which takes place only once and has more than two meanings. A good example is:

Weight-Watcher ice-cream: Spoil yourself and not your figure.

Here "spoil" has two meanings. The first meaning signifies enjoyingoneself whereasthe second spoil signifiesdestroyingsomebody's figure.Anybody who has a good style but is afraid of getting stout may be lucky to eat it [2, p.68-69].

A.Mirabela suggests one more type of the pun - idiom or proverb pun. She says that an idiom is an expression whose meaning cannot be deduced from the literal definitions and the arrangement of its parts, but refers instead to a figurative meaning that is known only through conventional use. Advertising language sometimes uses some people quoted proverbs or common sayings. These ads use the pun not only to enhance the attractiveness of advertising. The pun also embodies the art of advertising language, more so with a memorable advertising implication.

Idioms have multiword character, they are fixed and they have common figurative meaning. The phrase "to be in the same boat" has the literal meaning "to be in the same boat", and also the idiomatic figurative meaning "to be in the same difficult situation". For example:

Could you challenge us -and catch a bigger slice of the cake.

An idiom "a bigger slice of the cake" means to impart of theaccessible moneybenefits that you consider you have a right to. A picture represents two happy you women eating a cake. Idioms that have two meanings, an idiomatic and a literal meaning are of used creatively in pun [6,p.638-639].

The use of puns in advertising may be especially important in achieving advertiser's goal in certain social situations. By using a pun, the advertiser is able make an advertisement stand out and this has the potential to accomplish certain communicative goals better than if the message was expressed literally. The extra processing effort needed to process a pun helps to sustain the audience's attention for longer period of time and this makes the advertisement more memorable [4, p.58].

The most distinctive functions of the pun in the advertisements are aesthetic vocative ones.

Vocative function appeals to the languagefunction that thereviewers can takeactionsto perform as the text experts. Pun is a jest involving thejocular use ofa word in other sensesor words which vary in meanings but with the same or alike sound. It is important for ads to 
appeal the attention of the customers, e.g.: More cigarettes: Ask for More.

In this case, the pun reposes on thedual meaningsof the "more" word. It can beunderstood as a mark name of cigarettes. More can alsomention to more cigarettes of thismark name. The jocular use of "more"makes the ad very efficient and emphatic,so the customers can bestimulated to purchase the product.Another model: Coca Cola Coke refreshes you like no other can.

The word "can"has a simple meaning asthe aluminumcan used to hold liquid,mainly drinks, whereas it also can functionate as the modalverb in its homograph. Hence, this ad may be interpreted in dual ways:

Coke refreshes you like no other can(can refresh you).

Coke refreshes you like no other (drinks)can (refresh you).

Indeed, advertisements in that way mayamaze the consumers.

Aesthetic function cites to the language function that can evoke the readers sense of beauty. As the puns create the dual images from the phase of thesound and meaning, so the reviewers maylike some kind ofimagination or sensual pleasure. For instance:Raincheatah Raincoat: Catch the Raincheetah and cheat the rain.

Here, Raincheatah is the mark name for acloakwith similarly pronunciation as raincheater,whereasraincheater is invented from "windcheater" (waterproof raincoat). The reviewers may imaginethat theyplay with the rainwearingRaincheatah. Another example: Khadi Sat ReethtaHerbal Shampoo: Let's give your hair a spring touch.

This advertisement shows a kind of Shampoo with the impressive picture thatdemonstrates that after washing the hair will be like a waterfall, and spring has the meaning of elastic quality.Another example: Wigwam Sweet

\section{References}

1. Gulas, C. S., M.G. Weinberg (2006). Humor in Advertising: a Comprehensive Analysis. NY: M.E. Shape. P.241.

2. Xiang, L. (2006). On the Pun in English Advertisement. Canadian Social Science. - Laval: Canadian Academy of Oriental and Occidental Culture. Vol.2, Nr.2, P.68-70.

3. Zwicky, A. M., Zwicky, E. D. (1986). Imperfect Puns, Maredness, and Phonological Similarity: With Fronds Like These, Who Needs Anemones? Folia Linguistica. The Hague . Vol.20, Nr. 3-4, P.493-503.

\section{ПЕРЕКОНЛИВА СИЛА КАЛАМБУРІВ У БРИТАНСЬКІЙ РЕКЛАМІ}

\section{Л. О. Шанаєва-Цимбал}

Анотація.У статmі широко досліджено важливу роль каламбурів у британській рекламі. У сучасному світі реклама все більше привертає увагу фахівців різних областей знання: психології,
Corn: How about our sweet corn, you'll smile from ear to ear.

The word "Ear" has dual meanings:the first means an organ of hearing whilethe second means seed-bearing part of a cereal.So, "from ear to ear" signifies smilingbrightly or eating popcorn one after another.So it is easy to impress the readers and draw their attention to the ad product [2, p.69].

The other examples of different types of pun in advertising language are as follows:

House of Fraser: "Temptation on Every Level". (House of Fraser is a department store. This message reminds us that the whole is full of tempting things);

Toyota: "The Car in Front is a Toyota". (The double meaning is compounded by the fact that for a few years all Toyotas came with this slogan as a sticker on the rear window);

At\&T: If you want your business to pick up the phone. (It calls on how to use telephone services company with a view to enhancing the success of business and business contacts);

Holiday Inn: Don't have a weakend ... Have a WEEKENDER!(In this text advertising the hotel chain Holiday Inn deliberately distorts spelling of the word weekend);

Nimble: She's the nimblest girl around. Nimble is the way she goes. Nimble is thebread she eats. Light, delicious, Nimble. (In this advertisement, the word "nimble" as an adjective means clever, and as a proper noun, it is also the name of the product. So it has two meanings, orming a pun, which can arouse consumers buying desire).

Discussion. It is evident that pun plays an important role in advertising: it adds attractiveness, memo ability and effectiveness to advertising copy. Different types of pun are often used inmerchant advertisingas a periodic deviceto push a given service or productby drawing the reader's attention, creating humor and increasing persuasive force to the notification.

4. Abass, F. The use of Puns in Advertising. URL: $\quad$ http://leo.aichi-u.ac.jp/-goken/bulletin/pdfs/ No16/03AbassF.pdf

5. Li, Y. Linguistic Analysis of Puns in advertising English. URL: http://06bcgijkl.blogbus. com/logs/21570372.html

6. Mirabela, A. The Use of Wordplay and Idioms in Brands. URL: http://steconomice. uoradea.ro/anale/volume/2008/v1-internationalbusiness-and-european-integration/113.pdf

7. The Oxford English Dictionary. URL: http://oxforddictionaries.com 
культурології, журналістики, економіки та лінгвістики. Сьогодні важливу роль у нашому суспільному житті відіграє реклама. Вона має великий вплив на наше життя і може впливати на нас у різних сорерах. Реклама також інформує та керує багатьма важливими рішеннями, які ми приймаємо, не лише щодо автомобілів, якими ми керуємо, а й щодо того, чи йдемо ми на підприємницькі ризики, чи вибираємо вести здоровий спосіб життя, чи плануємо вийти на пенсію заздалегідь, чи жертвуємо гроші на благодійність. У процесі створення реклами вирішальне значення має мова, загально доступні терміни і вираження.

Англійський каламбур, як ефективний риторичний засіб поширений у літературних текстах, кіно і телевізійних комедійних шоу. Каламбур в рекламі, як технічний спосіб спілкування між рекламодавцем і клієнтом, відіграє величезну роль щодо залучення уваги людей, так як дуже часто на мовній грі грунтується комізм. Каламбур - одна з найпоширеніших форм мовної гри,і простір, що займає мовна гра і фрорми їі репрезентації безмежні, як $і$ простір, що займає мова як засіб спілкування. Гумор за своєю суттю привабливий для більшості споживачів, оскільки він є основним $і$ приємним компонентом нашої системи культурних цінностей. Позитивний зв'язок між гумором $i$ приверненням уваги було виявлено в багатьох різних типах ситуацій. Його рекомендували використовувати в торгових презентаціях, навчальних закладах, тренінгах, промовах після вечері та в рекламі багатьох різних видів продукції. 3 іншого боку, споживачам не завжди легко зрозуміти гру слів рекламодавця так як каламбур, як популярний літературний троп, постійно використовуює складові каламбури, а також жарти, засновані на омофонах і омонімах.

Ключові слова: інфрормація, гумор, реклама, переконання, сила, ЗМІ, Інтернет, преса, каламбури, рекламодавець, клієнт, увага, цінності, маркетинг, культура, психологія, лінгвістика. 